Rodríguez Ribero, M. (2013). Constructing victims in the land restitution law in Colombia: (re) making victims or moving towards justice? Revista Lebret (5). Bucaramanga, Colombia: Universidad Santo Tomás, pp 143-160

\title{
Constructing Victims in the Land Restitution Law in Colombia: \&(Re) Making Victims or Moving Towards Justice?*
}

\author{
La construcción de las víctimas en la Ley de Restitución de \\ tierras en Colombia: $¿(\mathrm{Re})$ hacer las víctimas o movimiento hacia \\ la justicia?
}

Mónica Rodríguez Ribero

\begin{abstract}
Summary
This paper critically analyses the process of social construction of the definition of victim in the Ley de Víctimas y Restitución de Tierras (Victims' and Land Restitution Law), enacted in Colombia in 2011. This law arose out of a negotiated agreement, and the main concern is the definition and cut-off point of 1991 for land restitution which is viewed as a form of deal or 'political settlement'. In this article, the main centre of attention is to understand the complex changes and shifts that took place in how a victim was defined in the context of this law. The methodology consists on a documentary review of statements made by the government, politicians, civil society and scholars during the four debates carried out in the Congress and the forums hold with civil society. This exercise was done through a social-constructivist approach and suggests that the victims' own priorities should be central to legal definitions of a "victim" in Colombia.
\end{abstract}

\section{Keywords}

Definition of victims, Law, Social construction, Political settlements

\section{Códigos de clasificación JEL: Y80, K39}

\begin{abstract}
Resumen
El artículo analiza de manera crítica el proceso de construcción social de la definición de víctima en la Ley de Víctimas y Restitución de Tierras promulgada en Colombia en el 2011. La atención se centra en los complejos cambios que se dieron en la definición de víctimas durante el proceso y en la decisión de otorgar la restitución de tierras por los despojos ocurridos a partir de 1991. Para estos efectos, se llevó a cabo una revisión documental de las declaraciones realizadas por el gobierno, políticos, sociedad civil y académicos en los debates del Congreso de la República y foros de socialización con la sociedad civil. Este ejercicio se desarrolló mediante la perspectiva teórica del Socio-constructivismo y concluye que las prioridades de la población afectada por el conflicto armado deben ser centrales para definir legalmente a las víctimas en Colombia.
\end{abstract}

Palabras clave

Definición de Víctimas, Ley, Construcción Social, Acuerdos Políticos.

\footnotetext{
* Este artículo es resultado de la investigación adelantada para obtener el título de Maestría en Development Studies: Human Rights, Gender and Conflict Studies del International Institute of Social Studies of Erasmus Universiteit Rotterdam, Países Bajos.

1 Magíster en Development Studies: Human Rights, Gender and Conflict Studies, International Institute of Social Studies of Erasmus Universiteit Rotterdam, Países Bajos. Correo electronico: rodriguezribero@gmail.com
} 


\section{Scope and methodology: technical considerations}

The long internal armed conflict in Colombia has generated millions of victims in a context that has to be understood in the light of complex explorations and multiplicity of actors and relationships. Between 2002 and 2010, during the government of the former president Álvaro Uribe, the existence of the conflict was systematically denied. This discourse shifted in 2010 with the government of the elected president Juan Manuel Santos. The tension between these two speeches reflects how ideologies and political interests have contributed to the construction of the social world as well as the different mechanisms used to reflect on social problems.

After more than fifty years of conflict, in 2011 the Colombian Congress studied and approved The Victims' and Land Restitution Law, VLRL, with the aim to provide economic and symbolic reparation to the victims. This Law establishes a set of judicial, administrative, social and economic benefits for this population, which enable them to fulfil their rights to truth, justice and reparations and guarantee of not repetition, through the realization of their constitutional rights ("Ministerio de Justicia", 2011).

While this law has been considered by some political sectors as an historical step to finally recognize the victims, there are different debates regarding its applicability, sustainability and efficiency in pursuing social justice. In particular, the aspect of the law that has motivated this research is the chronological delimitation for land restitution to those who have been victimized after the first of January of 1991. This delimitation implies that all groups and individuals who have been displaced out of their lands as a consequence of massacres, threats, torture, kidnappings, landmines, sexual violence, and other events occurred before 1991 are excluded from this law. In this sense, this article seeks to answer two specific questions: how is "victim" defined in the Victims' and Land Restitution Law 1448 of 2011? And how was the process of consultation conducted around the cut-off point of 1991 ?

In order to respond to the main research questions, this article analyses the debates conducted inside the Congreso de la República de Colombia (Colombian Congress) and forums hold with civil society between November 2010 and April 2011, with the aim to identify more broad perspectives on how a "victim" was defined in the VLRL. This analysis is carried out taking into account three main components: the process, the content and its meaning. These three aspects help us to reflect the motivations behind the chronological delimitation. This process also envisioned how ideologies can motivate the inclusion of certain issues in the national agenda.

At the same time, data review has been used in order to find possible causalities between the magnitudes of victims before and after 1991, and the decision of the lawmakers. Likewise, valuable interviews were collected and analysed through the website of different media in Colombia. Finally, two in depth interviews were hold with Eduardo Pizarro Leon Gómez, former president of the Comisión Nacional de 
Reparación y Reconciliación, CNRR (National Commission for Reparation and Reconciliation) and current ambassador of Colombia in The Netherlands and Eduardo Ramirez, executive director of Corporación Compromiso, institution that develops programs for peace and provides legal advice to victims of the armed conflict in the northeast region in Colombia.

The first part of this article presents Socio-Constructivism and Political Settlements as tools to analyse the process by which the definition was held. These two theoretical approaches emerged as a natural consequence due to the different influence observed between victims and politicians and how the arguments of the last ones corresponded to particular interests away from the reparation purposes. The second part, presents the discussion about the data of the victims in order to give a context on how the definition was influenced by previous facts. The third part presents the analysis of the main economic and political motivations given the four debates that took place in the congress and the consultation process held with civil society. Finally, the last part presents the concluding remarks.

\section{Tools for analyzing the definition of victim in the law}

The understanding of the world has been the subject of study of philosophers and political thinkers who, through different epistemological conceptions, have given meaning to society. This study emerges from the consideration that the definition of victim in the VLRL was socially constructed (Hart, 2012) and, therefore, influenced by economic and social conceptions on who is a victim and what kind of mechanisms they need to overcome their social conditions. In order to understand this complexity, two lenses are brought to this study: Socio-Constructivism Approach and Political Settlements. Socio-Constructivism guides the research on the components that constitute the definition and Political Settlements contributes to the study through an understanding on the logic of the bargaining between political actors. In this order of ideas, the conceptions of Finnemore and Sikkink (2011), Schneider and Ingram (1993) and Mushtaq Khan (2010) will be used to comprehend the dynamics, arguments and motivations that have influenced this definition.

\subsection{Social construction of categories of victims}

For the VLRL, the definition of who is considered victim, the instruments that have been deployed to give protection, land restitution and symbolic recognition, as well as the dynamics of the processes that took place in the Congress reflect specific world conceptions rooted in the Colombian society. As a result, the SocioConstructivist Approach "deals with the role of human consciousness in social life" (Finnemore and Sikkink 2001, p. 391, see also Sikkink, 2011) and will be used to underlie the arguments, motivations and explicit interests performed during the 
political debates in the Colombian Congress, as well as the responses of the victims' organizations on how the definition was developed to conclude to its final emission.

For the purpose of this study, the political influence on the decision of who deserves land restitution, who deserves economic reparations and who will be socially recognize as victims is going to be analyzed. The arguments presented in the debates respond to a social constructions of the category of victim based on stereotypes that "have been created by politics, culture, socialization, history, the media, literature, religion, and the like" (Schneider and Ingram, 1993, p. 335). In this regard, it is stated here that the arguments in politics stress the role of dominant groups constructing identities that affect the outcome of public policies. Hence, the definition of victim was influenced by interrelated forces that shaped the spectrum of reparation and protection, determining the inclusion and exclusion of certain population for the land restitution purposes, suggesting that beyond the facts about this situation, 'what makes public problems are the specific strategies of the stakeholders to promote a discourse linked to certain values, that contributes to a delimitation of the problem and, consequently, induces certain solutions' (Cejudo, 2008, p. 7).

For this reason, the problems identify in societies, led to the constructions of norms, rules and laws in order to regulate behaviours and bring justice to the citizens. From the point of analysis of the constructionist perspective, these regulations are influenced by several elements such as institutions, political and economic conditions, social values and discourses (Cejudo, 2008). In this way, individuals create and share speeches that have regulatory effects influencing the way in which victims are perceived by the state, and how these meanings are reproduced in different social, economic and legal spheres. Consequently, under this theoretical perspective, it is aimed to analyse those fixed ideas in relation to the forms and magnitude of land dispossession that occurred before 1991; arguments that have influenced the social construction of who is a victim in Colombia. In sume, constructivism serves several of the central questions of this study; particularly, in relation to the meanings and arguments and how discourses dominate the areas of formulation, consultation and decision making processes.

\subsection{Political settlements}

While can be inferred that reality is socially constructed, different actors have asymmetrical levels of participation in public policy decisions. In particular, Political Settlements is an approach that explains how the dominant and contending classes create alliances to achieve specific objectives. For the purposes of this article, some theoretical concepts of Mushtaq Khan are brought in this article with the aim to analyse the political coalition conformed to vote the VLRL. According with the author, these settlements are defined as a part of "social order based on political compromises between powerful groups in society that sets the context for institutional and other policies" (Khan, 2010, p. 4). 
In this regard, the main relationship that would be outline in the analysis is the one between power and political coalitions, understanding that "the power of different groups to contest, obstruct and oppose rules that are against their interests clearly affects the enforceability of institutions" (Khan, 2010, p. 18). Therefore, it is argued that an effective land restitution it has been hampered by economic interest of the powerful political class. In this way, holding power is understood for this analysis on a function of a number of groups to mobilize prevalent ideologies and symbols of legitimacy to consolidate its purposes (Khan, 2010). Therefore, this perspective complements the socio-constructivism scope and gives new tools to comprehend how elite groups influence and define fundamental policy decisions.

\section{Towards a definition of victim: information systems considerations}

The armed conflict in Colombia has left more than five millions of victims in the last three decades ('Red Nacional de Información', 2013). According to the current national service, provided by the Sistema Integrado de Información Humanitaria (Integrated Humanitarian Information System), SIDIH, from the Care and Reparation Unit for Victims, UV, there are 5.468.366 internally displaced person, IDPs, since 1985. This cumulative number increased from 2.471.422 in 2005, to 3.943.493 in 2011 (See Figure 1).

Figure 1. Cumulative Displacement in Colombia by Source, 1999-2011

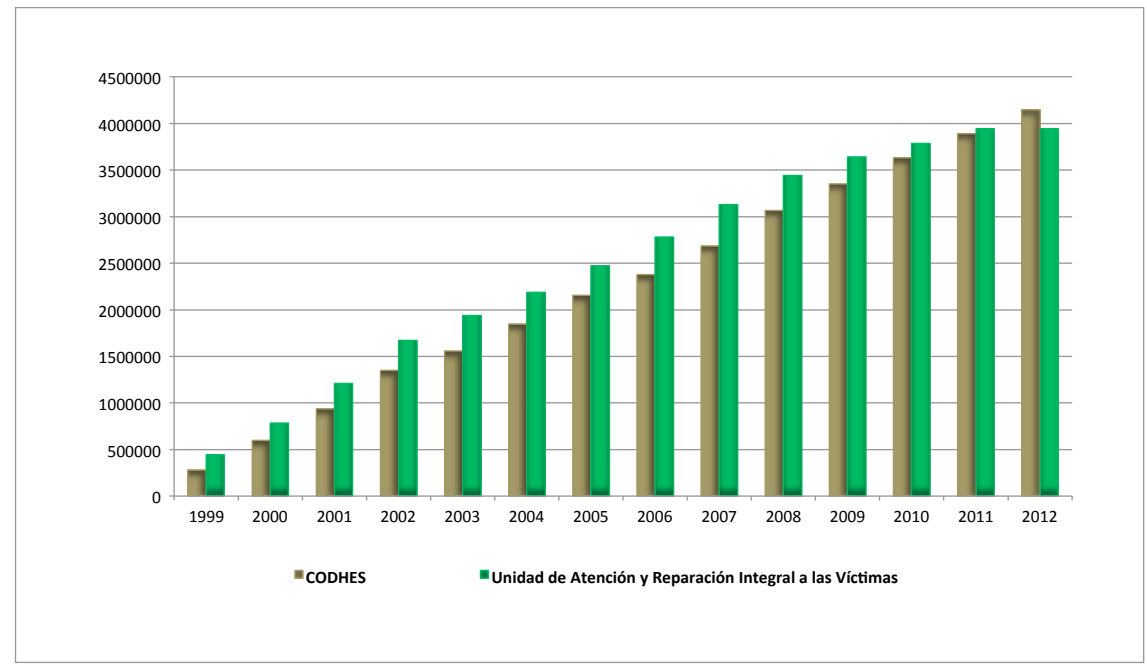

Source: Calculations by SIDIH, Graphic by the author. 
While forced displacement is the most visible phenomenon, the victims of the conflict are a very heterogeneous group. According to the Red Nacional de Información (National Information Network) the number of victims registered until march, 2014 is 6.231 .617 , from which 5.468.366 correspond to displacement and the remaining 763.251 correspond to other victimizing events defined by the VLRL. The figure 2 points out that the largest number of victims increased after 1995 then had a big jump in 2000 and had its peak in 2002, following by a subsequent decrease in 2009. This system presents the increasing number of victims as a result of the violence during the nineties that had an historical peak in 2002.

Figure 2. Number of victims of the armed conflict in Colombia by year

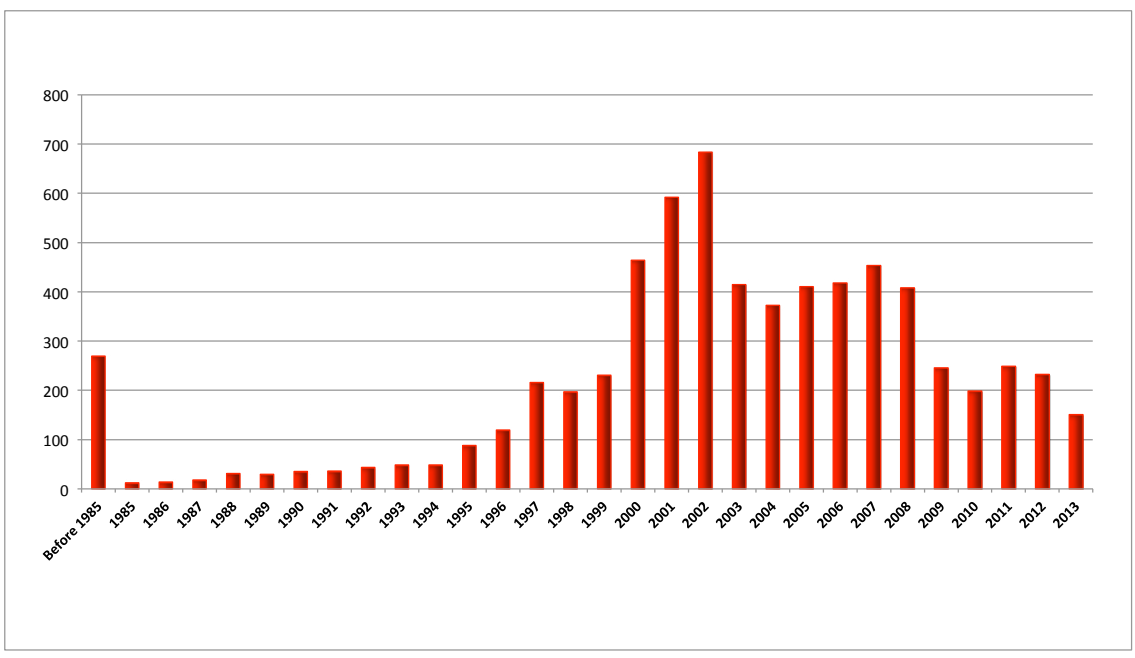

Source: calculations by Red Nacional de Información, Graphic by the author.

While this graphics are visual tools that explain the general behaviour of victimization in Colombia, there are two important points that need to be analysed. During the last five presidential administrations, the national information systems changed several times from the Ministerio de Justicia (Ministry of Justice) between 1995 and 1997 to the Sistema Nacional para la Atención y Reparación Integral a las Victimas (National System for Integral Care for Victims) SNARIV, institution created for the implementation of the VLRL in 2011. At the same time, the institutions that preceded the work done by the ministry were the Sistema Único de Registo (Unique Registration System), Sistema de Información de la Población Desplazada (Information System of IDPs) and Registro Único de Víctimas (Unique Register of Victims). Each of these institutions were the result of changing presidential administrations held every four years, leading to an institutional structuration according to new government policies. 
The changes of the institutions in charge of registration suggest that even though each government has the purpose to maintain high levels of efficiency, these changes generate distortion of information in relation to the mechanisms, parameters and criteria on which information is collected and systematized. In relation to the methodology that took place between 1995 and 1997, the Guía de Referencia Estadística (Statistics Reference Guide) of the web page Acción Social (one of the institution that previously systematized this information) reported that 'changes between one system to another one carried little information management standard, since the statements were made according to the criteria of each officer, the information associated to the period 1995 and 1999 is limited in quantity and quality' ('Acción Social',2007).

At the same time, data collection is based on a demand system. It means that the population had to approach to the offices to make the declaration. This type of system exclude certain individuals; particularly, due to "the costs assumed by them in transportation, the time required for the necessary paper-work and the fear reflected in the loss of anonymity" (Ibáñez and Velásquez, 2006, p. 1). Thus, the decision to declare depends largely on the vulnerability of households after displacement and the economic status of the place of origin.

Finally, the system only recognizes the last victimizing events. This means that if a person has been displaced multiple times, the system takes the most recent event ('Acción Social' as cited in Soledad and Egea, 2011) In other words, if a person was displaced in the eighties or nineties, and was displaced again in 2000, this individual or family will no longer count as a displaced in previous years. While this method only applies for people in situation of displacement, it should be noted that in Colombia the majority of victims present this condition, so it might be inferred that this systematization leads to underreporting of information.

The discussion carried out until now lead us to a preliminary finding: the decision to repair the victims only after 1991 was, in part, as a consequence of the information reflected in the official sources that demonstrates a much more significative number of IDPs in the nineties. Nevertheless, the magnitude of victims per year is not a sufficient element of decision for land restitution, regarding the lack of clarity and rigor of data collection during the eighties and procedures of the information system.

\section{Constructing the category of victim: deal-making and political settlements}

So far there has been presented one possible argument that could have influenced the definition of victim in the aspect related to the chronological limitation for the purpose of land restitution. In this section, one more element will be brought to the analysis: the political class. This is done from the perspective of critical constructivists who believe that "certain powerful groups play a privileged role in 
the process of social construction" (Finnemore and Sikkink 2001, p. 398). This angle of view reveals of great importance since the dynamics, arguments and interests that move the dominant political class are reflected in the final decision for the definition of victim in the VLRL. From this point of view, the socio-constructivist and Political Settlements allow us to understand how and why the definition in the VLRL was made to grant land restitution to victims affected by events occurred after 1991.

\subsection{Personality and Political Debate: towards a new ideology?}

The VLRL was presented in 2011 by the government of the president Juan Manuel Santos as the main goal for its political agenda (Semana, 2011). Previously, in 2008, the bill 157 of 2008, was presented by the Liberal Party with the aim to recognize the victims of the armed conflict, and was rejected by the Congress a petition of the official government at that time, the former president Alvaro Uribe, who asked to their representatives to vote against the bill: Just before the Senate voted the bill, Uribes' government unexpectedly asked to its coalition to reject the project, despite that the previous day they had reached an agreement to support the approval (Saffon, 2008).

In 2010, presidential voting took place. Antanas Mokus for the Partido Verde (Green Party) PV and Juan Manuel Santos for the Partido Social de Unidad Nacional (Social Party of National Unity) or Partido de la $U$ were the final contenders for the second round of voting. During this time, a coalition was conformed to support the official candidate while Antanas Mockus, on the other hand, decided to continue without the support of other political parties (Semana, 2010). In this juncture, the former candidate and only head of the Partido Liberal (Liberal Party), PL, Rafael Pardo, met with Santos and joined his campaign. This union was made with the commitment that LP presidential proposal on giving reparation to the victims would be included in the political agenda if Juan Manuel Santos won the presidential elections (Semana, 2010). At the end, Santos represented the traditional ideology and received the support of the most powerful political parties that made him the elected president of Colombia in 2010.

While it may be said that Santos, unlike its predecessor has had the political will to compensate this vulnerable population, it is important to analyse the motivations and interest to include the reparation in the political agenda and also maintaining a radical view in this aspect when both, the former and the current presidents come from the same political party.

In first place, Santos made politics belonging to the LP and later participated in a conservative vocation government. During the presidency of Alvaro Uribe, Santos was the Defence Minister and also one of the creators of the Partido de la $U$, taking possession as the president of Colombia in representation of this collective in August 2010. Thus, his political career has been spent within various political 
parties, specifically, the ideology of conservatism, neoliberalism and right centre position. Subsequently, he carried out a coalition called 'The Government of National Unity', in which various political parties converged to support the ruling government influencing the definition of victim and the political decisions that were taken out in relation to the VLRL. In this sense, different parties, in order to fulfil the vocation of unity and give support to the government, made a consensus in relation to this definition.

In the current Plan Nacional de Desarrollo 2010-2014 (National Development Plan) a design and implementation of a public policy to compensate the victims was specified with the aim to "create a transitional justice for victims of dispossession, so that they can restore lands that have been lost to the widespread of violence" ('Departamento Nacional de Planeación', 2010). While this agenda demonstrates the political will of the government to repair the victims, there is no explicit policy related to the VLRL and also a very widespread way to present this population since they are classified mainly as IDPs, excluding others types of victimization as a result of the conflict. Additionally, the importance of compensation has been highlighted in the "locomotives for growth and employment generation" section that contemplates the agricultural sector as an strategic area for the success of government policies and initiatives related to the restitution land and reparations to victims of forced displacement ('Departamento Nacional de Planeación', 2010, p. 206), which denotes a high neoliberal conception, in which restitution is accompanied by other policies such as security, rural development, inclusive business promotion and development of productive clusters.

\subsection{Debates in the congress of Colombia: political analysis on the definition of victim}

The arguments developed in a debate reflect the contexts and respond to "strategies and resources of individuals who promote and defend certain values and world views" (Cejudo, 2008, p. 3). These reasoning and propositions presented by politicians produce and reproduce categories and concepts that seek to persuade the definition of victims. Thereby, the main arguments during the four debates, as well as press releases and statements made afterwards by politicians and scholars are analysed here in order to comprehend how and why the definition was agreed.

In this order of ideas, the first debate took place on November 23, 2011 in the commission of the Cámara de Representantes (House of Representatives). During this debate, two main adjustments were made in the definition; the first one was the delimitation of 1991 for both, symbolic recognition and land restitution, and the inclusion of victims of the State. The Congress decided that the date from which the State must compensate the victims is 1991, creating a controversy for not taking into account the victims affected in previous years. In relation to this decision, the 
president of the Partido de la $U$, Juan Lozano, in an interview conceded to a national media, declared,

The date of 1991 was the result of an agreement that was held at the Presidential house with the LP, the Partido Conservador (Conservative Party), CP, the Partido de la $U$, the Justice Minister from the Partido Cambio Radical (Radical Change Party) CR and the President Juan Manuel Santos. It was not a decision that arose spontaneously, it was previously agreed, and with that consensus the parties came to vote the bill (Contravía, 2010).

According to this declaration, the political parties exercised their influence to mobilize their prevalent ideologies to consolidate their purposes (Khan, 2010). The decision was made in a closed door meeting with the main political leaders that integrate the official coalition, with absolute exclusion of social organizations and key institutions that directly exercise political control for the rights of the victims in Colombia. In this meeting, for example, the opposition parties like Polo Democrático Alternativo (Alternative Democratic Party), PD was excluded. In this way, the official forces lobbied and decided to set 1991 as the date from which the reparation would be granted.

The previous definition of this date sent one important message to the population. In first place, the lack of participation of all sectors that supposed to be include in this process. In this way, after the first debate, different organisations of civil society and representatives of political parties expressed their opinions about the decision in the House of Representatives. In particular, Senator Manuel Cepeda, from the $\mathrm{PD}$, pointed out the consequences of this proposal. His arguments were based on the dynamics of internal forced displacement and the responsibility of the State to recognize the victims. In this regard, he expressed that regularly victims have suffered multiple displacements and also reacted in this debate expressing that 'reparation is not an act of solidarity but a duty of the Congress to protect and restore the damage that has been inflected for decades over the population' (Contravía, 2010).

As mentioned by the Socio-Constructivism Approach, "policy sends messages about what government is supposed to do, which citizens are deserving (and which not), and what kinds of attitudes and participatory patterns are appropriate in a democratic society" (Schneider and Ingram, 1993, p. 334). The arguments of senator Cepeda are based on the historical dispossession of land. He had mentioned the need of recognition of those events occurred before 1991. However, the proposal generated within the Partido de la $U$ showed there were a previous agreement, either as a result of the displacement data or other reasons that were not specified in the statement made by senator Lozano.

In the second debate in one commission of House of Representatives that took place on December 13, 2010, the bill had an important affirmation, set again the year 1991 as the start limit from which the condition of victim would be recognized. 
Initially, 'the second Commission in the Senate considered 1995, but after a long discussion, the Congress choose 1991 because it was the year that the National Constitution was enacted' (Caracol Radio, 2010). Although it was a historic event for the Colombian State, the use of this date as a reference point to define the universe of victims contradicts the reasons on why this constituent was carried out in first place. Precisely, the Asamblea Nacional Constituyente (Constituent National Assembly) was conducted with the purpose of include new realities related to the conflict that were not expressed in the constitution of 1986. In this sense, politicians should have considered that, before 1991, many victims were affected by emerging paramilitary forces, private groups created by drug dealers, landowners with support of high military commands.

The reactions to this proposal came from different perspectives and new issues were raised in the discussion. In first place, the senator Guillermo Rivera, said: 'even though the law was in the agenda of the national government, the Interior Minister said that the issue of the date can be revised during the two remaining debates in the Senate, according to a study of the final costs' (Caracol Radio, 2010). This critique reflects how the reparation was conditioned from the government to economic instruments. The fact that the State has sent these signals from this preliminary state reveals the way it has handled the status of victim in the Colombian national context.

The third debate in the Senate was conducted on March 02, 2011. The discussion went primarily around the retroactivity and funding. Until the second debate in House of Representatives, the bill kept the date of January 1 of 1991 for both recognition and land restitution. Nevertheless, during this debate, it was suggested that the date from which the victims should be recognize should have been January 1, 1985, while economic reparation and land restitution would be given only to those who have been victimized after January 1, 1991. This decision was taken out of fear that 'victims could invoke the right to equal protection and demand in the Constitutional Court by those who were previously victimized' ( $L a F M, 2010)$. In this rationality, 1991 was accepted for land restitution and 1985 was extended for purposes of symbolic recognition and guarantees of non-repetition. Although this is a preliminary evidence of the motivations behind the chronological delimitation, it is an ambiguous argument that excludes the victims before 1985, who could have also demanded, and does not indicate any argument on why the State should not give land restitution for those affected prior 1991.

During this debate, a rejected position to this proposal was permanent by the PV. This political party insisted in the inclusion of all victims affected during the eighties. In this plenary, the senator Jorge Eduardo Londoño insisted that the reparation should be taken from January 1, 1980 explaining that "giving reparation to the victims of the eighties would not increase by a large percentage the economic weight of the reparation project" (Alianza Verde, 2011). The fact that Senator Londoño defended his 
position evidencing the economic motives presented by the opponents of extensive reparation to all victims, express how the restitution process was conceived.

On the other hand, during a personal interview conducted with Eduardo Pizarro, current ambassador of Colombia in The Netherlands and former president of the CNRR, he emphasized that all dates for restitution are considered to be arbitrary. This is the case of 1991 in the VLRL. However, for the particular case of Colombia, the reparation for all victims is limited by the lack of property rights in rural areas. According to Pizarro:

Only $50 \%$ of rural areas have notary titles. In order to return the land to the real owners, the State have to review all the rural property rights in Colombia, which is impossible since 1950 most of the land has been appropriated illegally as a consequence of the bipartisan violence that characterized those years ${ }^{2}$.

Which evidence that there are a number of limitations that arise from social, political and economic behaviour of several decades ago that prevent a proper process of land restitution to victims of violence. Finally, during the fourth debate in the Senate, hold on March 24, 2011 the law was approved. Voting took place with 63 positive votes and 10 votes against the bill, mostly from the PD, political party that expressed its rejection since the second debate (El Colombiano, 2011). According to the senator Luis Carlos Avellaneda from the PD, the definition of the victims leaves behind citizens affected by crimes committed as a result of the escalation of drug violence in the eighties:

The guerrilla kidnappings began in 1980, starting with 16 and increases to 2.198 cases at the end of that decade. In this way, provide reparation since 1991 left behind all the hostages and their families, as well as 3.500 victims of the political persecution carried out by illegal right-wing groups (Noticias del Senado, 2011).

Despite the various arguments presented in favour of an extension in the range definition of victim, at the end, the law included two periods for the reparation rights. The economic compensation and symbolic recognition will be given from the first of January of 1985, and land restitution will be granted from the first of January 1991. The main controversy was presented by the Partido de la $U$ that objected in the law the explicit recognition of the armed conflict in Colombia. The government decided to maintain this statement, adding the suggestion of labelling the Colombian Revolutionary Armed Forces, FARC ${ }^{3}$ as terrorist group. In this way, the bill was approved on May 24, 2011, in consensus with the main political parties.

In this pact was absent the PD, that did not agreed with some articles of the law, mainly related to the definition as well as its process of social construction.

2 Personal interview with E. Pizarro on formatting MA thesis, at the Institute of Social Studies, The Hague, 06 August 2013.

3 Fuerzas Armadas Revolucionarias de Colombia. 
The fact that the bill was previously agreed by politicians of the coalition were the main reasons why the $\mathrm{PD}$, as a main opposition force, announced during this debate the withdrawal of this political party in the conciliation of the law. According to remarks made by Iván Cepeda, a representative of the PD and official spokesman of the Movimiento de Víctimas de Crimes del Estado (Movement of Victims of State Crimes), MOVICE:

The PD values the existence of a law that aim to give restitution to the victims. During these months, we have presented diverse initiatives (more than 200 propositions) to try to improve the text that today has been conciliated by the National Unity. Nevertheless, our reluctance to sign this law relies on the fact that it was previously defined before coming to this table between the President of the Republic and the benches of the government. Thus, we regret this situation in a debate that should have been democratic and constructive' (Mesa Nacional de Víctimas, 2011)

The statement presented above claims inconsistencies not only in the content of the bill but also on how the procedure took place, which means that "the content of the speech is important, but also the construction process of the discourse" (Schmidt, as cited in Cejudo 2008, p. 11). The discourse presented by Cepeda claims important aspects of the text that will contribute the reparation of the victims but made specific statements regarding the way the bill was agreed between the main political forces. The fact that despite the historical armed conflict in Colombia, certain population is regarded as a beneficiary of the law in a context of exclusive debate and political participation, demonstrate not only a social construction on who are the victims in Colombia, but also a particular set of political interests.

\subsection{Five forums: 'victims' perspectives}

One of the main added values that the government and senators who supported this bill expressed was the high level of participation in the forums that were conducted in order to socialize the project with civil society. Nevertheless, according to public statements made by social organizations through their official websites, as well as complains made by leaders of victims through local television and national newspapers, during five months debates in the Congress the inclusion of victims in the discussion of the bill was minimum.

These events were scheduled at the national level in the main capital cities which generated a limited access of victims located in remote regions of the country with little transport connectivity. In some of these events, organizations of victims complained about the absence of state institutions which demonstrated the lack of importance given to this part of the process. These events were mainly suggested and promulgated by civil society in an attempt to raise awareness among the population about the content of the bill. These proposals were presented based on consensus of victim's opinions regarding testimonies of massive land grabbing during the eighties. 
In this order of ideas, on November 12 of 2010 the first Consulta Regional de Victimas (Regional Hearing of Victims) was held in Medellín. This hearing, organized by MOVICE, had the participation of the Senator Iván Cepeda Castro and Alexander López from the PD. During this hearing the victims expressed their concerns regarding the definition contented in the bill; particularly, the delimitation for date of events. In this regard, the MOVICE released to the public opinion a written speech in relation to the second debate in the plenary of the House of Representatives in which the movement drew attention about the time coverage:

Despite the inclusion of victims of agents of the state in the definition of victim, the limitation to those who have suffered by events after the nineties is a situation that ignores the dimension of the crimes committed prior to this date, especially in the eighties in which a great upsurge of social and political violence was committed by performing of the first paramilitary massacres and significant assassinations, genocides, massacres and disappearances; all related to the increase of socio-political violence in the country (MOVICE, 2010).

Subsequently, on March 3, 2011, during the hearing conducted by the Mesa Nacional de Victimas (National Bureau of Victims) MNV, the importance of the bill was recognized, particularly for being an issue that finally arise in the national agenda. Nevertheless, the MNV noted with concern the huge gaps in the content of the bill regarding the definition given that excludes victims of serious human rights violations in previous years. This position was shared by several organizations. For instance, the Comisión Colombiana de Juristas (Colombian Commission of Jurists), $\mathrm{CCJ}$, expressed the lack of inclusion and socialization of the population affected by the bill: "One of the most important observations we can make is the absence of adequate mechanisms to ensure the participation of victims in the formulation and design" (CCJ, 2011,). For the purpose of their statement, the CCJ reviews the reports presented by the Ministerio de Agricultura y Desarrollo Rural (Ministery of Agriculture and Rural Development) evidencing that the regulation was progressing without socialization.

This thought was shared by civil organizations. During a personal interview conducted with Eduardo Ramirez, executive director of Corporación Compromiso, he commented that:

While there have been institutional efforts to repair the victims, there are strong economic interests of illegal groups impeding this process. At the same time, there is a misrepresentation of what a victim really needs. Land restitution it should be granted from a holistic perspective, considering the safety of returnees and the restitution in all its dimensions ${ }^{4}$.

Personal interview with E. Ramírez on formatting MA thesis, at the Institute of Social Studies, The Hague, 02 August 2013. 
During the program of analysis about the VLRL made by Contravia, politicians from the LP, scholars and the former candidate to the presidential elections and current major of Bogotá city, Gustavo Petro, agreed in the importance to support an inclusive law for victims. In this regard, Gustavo Petro inferred that the land grabbers are combining three forms of contestation: the legal, justice and murders. The second one is very important because "these forces move their political representatives inside the congress" (Petro Video, Contravía, 2010). This is the reason why, according with Petro, it was observed leaders of specific political parties attacking the bill and that is why they wanted to delimit the reparation since 1991.

In the analysis made by Petro, 1991 represented the interests of land grabbers (Contravía, 2010). This statement is also supported by Camilo Sánchez León, researcher of the Centro de Estudios de Derecho, Justicia y Sociedad (Centre for Law, Justice and Society), who argues that there are different reasons why during the debates in the Congress, the political class decided to delimit the date of reparation only until 1991: "A serious exercise of truth, justice and reparation scares some people who committed and supported crimes, who feel that their economic and judicial responsibility can be affected" (Camilo Sanchez video, Contravía, 2010). Hence, as stated by the social organizations themselves, "the VLRT was already agreed and it was reflected of the voting process that took place inside the Congress of the Republic" (Contravia, 2011). Thus, the political coalition exerted a major influence on this decision, despite the multiple manifestations of victims, social organizations and other political parties belonging to the opposition that advocated for a broader definition of victim.

\section{Concluding remarks}

The process carried out in the Senate shows that while there may be political will of certain sectors to compensate the victims of armed conflict, the worldviews, conceptions and interests of the dominant political class, developed long time ago, have impacted on the mechanism used to defined and give reparation to the victims. The initial main arguments used to reject the possibility of restoring land before 1991 were issues related to fiscal sustainability, the new Colombian constitution enacted in 1991, and the magnitude of victims in the nineties. During the four debates in the Congress it was observed the overlapping of economic interests of the political class over the State's obligations towards its victims.

This research found that the content of the laws are important but also its construction process. The definition of victim in the VLRL was constructed within particular political sectors, in which the dialogue between organizations of civil society was rejected. This founding was supported by the statement made by Senator Juan Lozano: "I do not understand why there are criticisms of this delimitation when it was a consensus agreed with the leaders of the political parties in the presidential 
house" (Contravía, 2010). This discourse excludes political participation different from the traditional parties, which denotes the mentality in which decisions are made: exclusion of the vulnerable sectors.

In conclusion, the definition of victim in the new law arose out of a negotiated agreement between a new government and a coalition of other political parties. This agreement involved complex changes and shifts in the definition of victim. In spite of the forums and four Congress debates, meaningful spaces for victim participation to contribute to the legal construction of "victim", were claimed to have been very limited in practice. The final cut-off date of 1991, arose as government again shifted its discourse because of underlying economic and political motivations. This shows that although it is a law that has been designed in order to bring justice, its purpose is far from being achieved. Thus, any legislation involving vulnerable population must to include their claims and considerations. Futures decrees and bills must ensure adequate inclusion of civil society, with the aim of building inclusive mechanism of participation.

\section{References}

Acción Social. (2007). Guía de consultas salidas estadísticas páginas web Acción Social. Accessed 1 October 2013. Available: <http://www.yumpu.com/es/ document/view/14840312/guia-de-consulta-salidas-estadisticas-pagina-webaccion-social>

Caracol Radio. (2010). Al Senado pasó la ley de víctimas tras aprobarse en la Cámara. Accessed 14 December 2010. Available: <http://www.caracol.com.co/ noticias/actualidad/al-senado-paso-la-ley-de-víctimas-tras-aprobarse-en-lacamara/20101214/nota/1398192.aspx>

Cejudo, M. (2008). Discurso y políticas públicas: enfoque constructivista. Centro de Investigación y Docencias Económicas. Accessed 16 September 2013. Available: http://www.cide.edu/publicaciones/status/dts/DTAP\%20205.pdf>

Comision Colombiana de Juristas (CCJ). (2011). Ley reparara a cuatro millones de víctimas. Accessed 24 june 2011. Available: http://www.coljuristas.org/ prensa/2011/ec_26-05-2011.html>

Contravía (2010). Análisis sobre la ley de víctimas en Colombia Accessed 29 september 2013. Available: http://www.youtube.com/watch?v=OBTtqg6Vkzw

Departamento Nacional de Planeación (DNP). (2010). Plan Nacional de Desarrollo 2010-2014. Accessed 3 August 2013. Available: https, p.//www.dnp.gov.co/pnd/ pnd20102014.aspx> 
El Colombiano. (2011). La ley de Víctimas fue aprobada por el Senado. Accessed 24 May 2011. Available: <http://www.elcolombiano.com/BancoConocimiento/A/a sancion_presidencial_la_ley_de_víctimas/a_sancion_presidencial_la_ley_de_ víctimas.asp>

Finnemore, M. and Sikkink, K. (2001). Taking Stock: the construcvist research program in international relations and comparative politics, Annual Reviews (4), 391-416. Accessed 8 September 2013. Available: <http://www.annualreviews. org/doi/pdf/10.1146/annurev.polisci.4.1.391>.

Hart, H. (2012). The Concept of Law. Oxford: Oxford University Press.

Ibáñez A. and Velásquez, A. (2006) El proceso de identificación de víctimas de los conflictos civiles: una evaluación para la población desplazada en Colombia. Centro de Estudios sobre Desarrollo Económico. Accessed 21 September 2013. Available: <http://economia.uniandes.edu.co/investigaciones_y_publicaciones/ CEDE/Publicaciones/documentos_cede/2006/el_proceso_de_identificacion_ de_víctimas_de_los_conflictos_civiles_una_evaluacion_para_la_poblacion_ desplazada_en_colombia>

Khan H. M. (2010). Political settlements and the governance of growth-enhancing institutions [On line]. Accessed 05 September 2013. Available: http://eprints. soas.ac.uk/9968/1/Political_Settlements_internet.pdf>

LaFM. (2010). Principales puntos de la Ley de Víctimas. Accessed 3 June 2013. Available: http://www.lafm.com.co/noticias/nacional/01-06-11/principalespuntos-de-la-ley-de-v-ctimas

Mesa Nacional de Víctimas. (2011). Polo no firma conciliación de víctimas. Accessed 10 April 2013. Available: http://www.youtube.com/watch?v=5sPWn4p3nGA

Movimiento Nacional de Víctimas de Crímenes de Estado (MOVICE). (2010). Pronunciamiento público sobre el proyecto de ley de víctimas Accessed Agust 10, 2013. Available: http://www.cjlibertad.org/index.php?option=com_content\&v iew =article \&id=399:pronunciamiento-publico-sobre-el-actual-proyecto-de-leyde-víctimas\&catid=34: movice-codehsel $\&$ Itemid=37

Noticias Senado (2011). Senador Avellaneda presentó ponencia alternativa al proyecto de ley de víctimas. Accessed 1 April 2013. Available: http://www.senado.gov.co/ sala-de-prensa/noticias/item/11850-se-radica-ponencia-alternativa-al-proyectode-ley-de-víctimas

Saffon, M. P. (2008). Revictimizando a las víctimas [Online]. Accessed 30 June 2013. Available: http://www.parcomun.org/noticias/257/revictimizando-a-las-víctimas-

Semana. (2010). Por qué Mockus dice No a las alianzas? Accessed 1 June 2011. Available: http://www.semana.com/politica/articulo/por-que-mockus-dice-noalianzas/117491-3 
Semana. (2011). Congreso le entregó a Santos tres leyes clave para su gobierno. Accessed 1 June 2011. Available: http://www.semana.com/politica/articulo/ congreso-entrego-santos-tres-leyes-clave-para-su-gobierno/240735-3

Schneider, A. and Ingram, H. (1993). Social construction of target populations: implications for politics and policy. American Political Science Review: Accessed 8 Sep 2013. Available: http://www.jstor.org/stable/2939044.

Soledad, J. and Egea, C. (2011). El análisis del desplazamiento interno en Colombia con base en el Registro Único de Población Desplazada (RUPD): localización y características (2000-2007). Scripta Nova Revista Electrónica de Geografía y Ciencias Sociales. Accessed 21 September 2013. Available: http://webarchive-net.com/page/531008/2012-10-26/http://www.red-redial.net/referenciabibliografica-61700.html> 